\title{
ANALISIS BIOAUTOGRAFI DAN KARAKTERISASI DENGAN FTIR PADA FRAKSI DAUN LABU SIAM (Sechium edule (jacq).SW) TERHAD AP Porphyromonas gingivalis DAN Streptococcus mutans
}

\author{
Analysis Of Bioautography And Characterization With Ftir In Siam (Sechium \\ edule(jacq) .SW) Leaf LEAF From Porphyromonas gingivalis \\ and Streptococcus mutans
}

\author{
Laila Susanti ${ }^{\star}$, Isbiyantoro, Septiana Simanjuntak \\ Program Studi Farmasi, Universitas Tulang Bawang Lampung \\ e-mail : lailasusanti80@gmail.com \\ 081323791775
}

*corresponding author

\begin{abstract}
Siamese pumpkin leaves are one of the plants that have antibacterial properties. Compounds that act as antibacterial are flavonoite, tannin, triterpenes, alkaloids, and saponins. The aim of this study was to prove the antibacterial activity of ethanol hexane and chloroform fraction of pumpkin siam leaves and characterize the functional groups of active compounds from pumpkin siam leaves (Sechium edule (jacq). SW) with FTIR spectrophotometers. The extraction process of Siamese Pumpkin leaves was carried out by maceration method using $70 \%$ ethanol. The extract was continued with the fractionation process with ethanol, $n$-hexane and chloroform solvents. Antibacterial activity testing using the well method with a concentration of $100 \%$, positive control chlorhexidi and negative control aquadst. The compound content test used the Thin Layer Chromatography (TLC) method with the stationary phase using silica plate G60 F254 and comparison of the mobile phase of chloroform: methanol: water (2: 5: 3) ( $\mathrm{v} / \mathrm{v}$ ). Bioautography test using the contact method, namely the elution TLC plate, was placed on the NA medium containing a bacterial suspension for 3 hours. Antibacterial test results The largest ethanol fraction of pumpkin leaves was at a concentration of $100 \%$ with a diameter of inhibition zone of $11.49 \mathrm{~mm}$ on P. gingivalis while $16.04 \mathrm{~mm}$ in S. mutans. The results of TLC showed the presence of flavonoids with a price of Rf 0.47 and tannin with a price of Rf 0.84. Bioautography results showed a inhibition zone with a price of Rf 0.49 in the bacteria $P$. gingivalis and $S$. mutans which are flavonoid compounds. Characterization by FTIR spectrophotometer $\mathrm{O}-\mathrm{H}$ phenol, $\mathrm{C}=\mathrm{C}$ aromatic, $\mathrm{C}-\mathrm{O}-\mathrm{C}$ ether, aromatic $\mathrm{C}-\mathrm{H}$ functional group
\end{abstract}

Keywords: (Sechium edule (jacq) .SW). Porphyromonas Gingivalis, Streptococcus mutans, TLC, Bioautography and FTIR

\section{Abstrak}

Daun Labu siam merupakan salah satu tanaman yang memiliki khasiat sebagai antibakteri. Senyawa yang berperan sebagai antibakteri adalah flavonoit, tanin, triterpen, alkaloid dan saponin. Tujuan dari penelitian ini adalah untuk membuktikan adanya aktivitas antibakteri fraksi etanol n-heksan dan kloroform daun labu siam dan mengkarakterisasi gugus fungsi senyawa aktif dari daun labu siam (Sechium edule (jacq).SW) dengan spektrofotometer FTIR. Proses ekstraksi daun Labu siam dilakukan dengan metode maserasi menggunakan pelarut etanol $70 \%$. Ekstrak dilanjutkan dengan proses fraksinasi dengan pelarut etanol, nheksan dan kloroform. Pengujian aktivitas antibakteri menggunakan metode sumuran dengan konsentrasi $100 \%$, kontrol positif klorheksidi dan kontrol negatif aquades. Uji kandungan senyawa menggunakan metode Kromatografi Lapis Tipis (KLT) dengan fase 


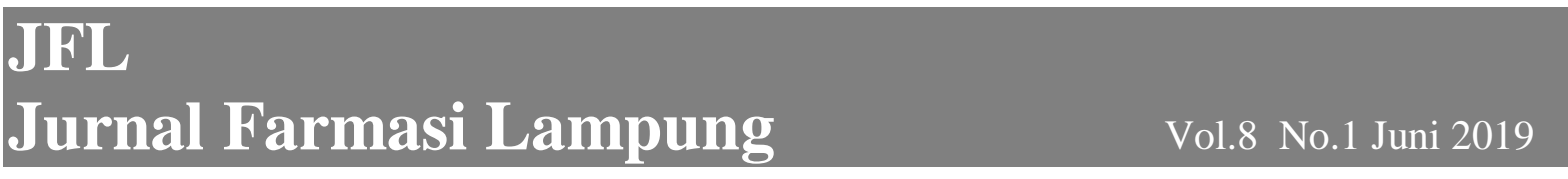

diam menggunakan plat silika $\mathrm{G}_{60} \mathrm{~F}_{254}$ dan perbandingan fase gerak kloroform :metanol : air $(2: 5: 3)(\mathrm{v} / \mathrm{v})$. Uji bioautografi menggunakan metode kontak yaitu plat KLT hasil elusi diletakkan diatas media NA yang berisi suspensi bakteri selama 3 jam. Hasil uji antibakteri Fraksi etanol daun labu siam paling besar yaitu pada konsentrasi $100 \%$ dengan diameter zona hambat sebesar $11,49 \mathrm{~mm}$ pada $P$. gingivalis sedangkan $16,04 \mathrm{~mm}$ pada $S$. mutans. Hasil KLT menunjukkan adanya senyawa flavonoid dengan harga $\mathrm{Rf} 0,47$ dan senyawa tanin dengan harga Rf 0,84. Hasil Bioautografi menunjukkan adanya zona hambat dengan harga Rf 0,49 pada bakteri $P$. gingivalis dan $S$. mutans yang merupakan senyawa flavonoid. Karakterisasi dengan spektrofotometer FTIR didapatkan gugus fungsi $\mathrm{O}-\mathrm{H}$ fenol, $\mathrm{C}=\mathrm{C}$ aromatik, $\mathrm{C}-\mathrm{O}-\mathrm{C}$ eter, $\mathrm{C}-\mathrm{H}$ aromatik

Kata Kunci : (Sechium edule (jacq).SW). Porphyromonas gingivalis, Streptococcus mutans, KLT, Bioautografi dan FTIR

\section{PENDAHULUAN}

Kesehatan gigi dan mulut merupakan hal yang penting, karena gigi dan mulut yang sehat memungkinkan seseorang untuk makan, berbicara dan bersosialisasi dengan nyaman tanpa mengalami rasa sakit. Namun, pada kenyataannya kondisi ini sulit dicapai [1]. Penyakit gigi dan mulut masih menjadi permasalahan kesehatan yang cukup besar di Indonesia. Berdasarkan Riset Kesehatan Dasar (RISKESDAS) Tahun 2013 terdapat $25,9 \%$ penduduk Indonesia mengalami penyakit gigi dan mulut. Penyakit gigi dan mulut tersebut sebagian besar diakibatkan oleh infeksi mikroba. Hal ini disebabkan rongga mulut paling banyak terlibat dalam terjadinya berbagai penyakit diantaranya penyakit yang disebabkan bakteri Porphyromonas gingivalis dan Streptococcus mutans [2].

P. gingivalis adalah salah satu bakteri gram negatif anaerob penyebab terjadinya peradangan yang menghancurkan jaringan pendukung sehingga menyebabkan kehilangan gigi yang disebut dengan periodontitis. Penyakit ini menyerang jaringan periodontal yang mengelilingi gigi dan berfungsi sebagai penyangga gigi yang terdiri dari gingiva, sementum, ligamen periodontal, dan tulang alveolar [3]. S.mutans adalah bakteri gram positif berbentuk bulat yang khas membentuk pasangan atau rantai selama masa pertumbuhannya [4]. S.mutans merupakan bakteri yang mempunyai kemampuan dalam proses pembentukan plak dan penyebabnya karies gigi. Karies gigi merupakan suatu penyakit infeksi yang dapat menular dan terutama mengenai jaringan keras gigi [5]. Karies sebagian besar disebabkan karena adanya infeksi bakteri, sebagai pencegahan agar tidak terjadi infeksi dan gigi berlubang dianjurkan untuk menyikat gigi secara teratur dan menggunakan obat kumur. Perawatan gigi yang baik merupakan usaha yang tepat untuk menghindari komplikasi penyakit yang diakibatkan oleh infeksi bakteri penyebab karies gigi yakni P.gingivalis dan S.mutans.

Salah satu obat kumur yang digunakan untuk mengurangi jumlah koloni bakteri yaitu klorheksidin. Berdasarkan penelitian yang telah dilakukan menunjukkan bahwa klorheksidin terbukti dapat menghambat pembentukan plak, mengurangi inflamasi gingival dan mencegah karies gigi [6]. Namun, obat kumur ini telah dilaporkan memiliki sejumlah efek samping yaitu penyebab warna coklat pada gigi, rasa yang kurang enak, pembengkakan parotis yang unilateral atau bilateral, dan peningkatan pembentukan kalkulus supra gingival [7]. Oleh karena itu pengobatan alternatif diperlukan untuk menghambat pertumbuhan plak dengan menggunakan tumbuhan herbal [8] antara lain jahe mampu menghambat $P$. gingivalis dengan konsentrasi $6,25 \%$ dengan rata-rata diameter zona hambat 10,6 mm [9], daun tembakau dapat menghambat $S$. mutans, 
dengan konsentrasi $80 \%$, sedangkan $P$.gingivalis dan Candida albicans dengan konsentrasi $100 \%$ [10] dan estrak bunga cengkeh dapat menghambat bakteri S.mutans dengan zona hambat $18,2 \mathrm{~cm}$ [3].

Besarnya potensi tanaman sebagai antibakteri menjadi suatu ketertarikan mencari senyawa aktif dari tanaman lokal yang tumbuh di Indonesia. Salah satu tanaman lokal yang telah lama digunakan masyarakat sebagai pengobatan adalah labu siam (Sechium edule (Jacq.) Sw). Data empiris menyebutkan bahwa daun labu siam digunakan untuk meningkatkan hemoglobin [11], penghasil enzim protease [12], antioksidan [13], dan antimikroba [14]. Labu siam merupakan salah satu tumbuhan obat Indonesia dari suku Cucurbitaceae. Daun labu siam memiliki kandungan senyawa kimia seperti saponin, steroid/triterpenoid, tanin, flavonoid, protein, lemak, karbohidrat, kalsium, zat besi dan mineral. [11]. Berdasarkan penelitian sebelumnya ekstrak etanol daun labu siam dapat menghambat $P$. gingivalis penyebab priodontitis dengan konsentrasi $40 \%$, menggunakan metode difusi [15].

Selama ini pengobatan yang biasa dilakukan untuk penyakit karies dan gigi berlubang diatasi dengan menggunakan antibiotik. Penggunaan antibiotik yang berlebihan bisa membuat mikroba patogen menjadi resisten. Oleh sebab itu untuk mengatasi hal tersebut maka perlu dicari arternatif pengobatan untuk mengatasi penyakit infeksi, salah satunya dengan pencarian senyawa aktif antibakteri yang terdapat pada daun labu siam. Tujuan penelitian ini untuk mengetahui fraksi etanol, n-heksan dan kloroform daun labu siam dapat menghambat pertumbuhan bakteri P.gingivalis dan $S$. mutans. Untuk mengetahui agen senyawa aktif daun labu siam secara bioautografi. Untuk mengkarakterisasi gugus fungsi senyawa aktif dari daun labu siam hasil dari uji bioautografi dengan FTIR

\section{METODE PENELITIAN}

\section{Alat dan Bahan}

Alat yang digunakan alat-alat gelas, rotary evaporator. Bahan yang digunakan daun labu siam, biakan bakteri P.gingivalis, biakan bakteri $S$. mutans, media Nutrien Agar (NA) dan Nutrient Broth (NB), aquades, etanol $70 \%\left(\mathrm{C}_{2} \mathrm{H}_{6} \mathrm{O}\right)$, kloroform $\left(\mathrm{CHCl}_{3}\right)$, n-heksan (C6H15) Amoniak $\left(\mathrm{NH}_{3}\right)$, Liebermann-Burchard, besi (III) clorida $\left(\mathrm{FeCl}_{3}\right)$, pereaksi Bouchardat.dan $\mathrm{H}_{2} \mathrm{SO}_{4}$

\section{Pembuatan Ekstrak dan fraksi daun labu siam}

Simplisia daun labu siam sebanyak 500 gram masukan kedalam botol gelap kemudian ekstrak dibuat dengan cara maserasi menggunakan cairan penyari etanol $70 \%$ dengan 7 kali remaserasi. Selanjutnya maserat diuapkan dengan menggunakan rotary evaporator hingga diperoleh ekstrak cair. Ekstrak yang diperoleh difraksinasi dengan ditambahkan pelarut etanol dan n-heksan dengan perbandingan 1:1 hingga didapat fraksi etanol dan fraksi n-heksan. Kemudian fraksi etanol difraksinasi kembali dengan penambahan pelarut kloroform dengan perbandingan 1:1 hingga didapat fraksi etanol dan kloroform. Kemudian fraksi etanol yang diperoleh diuapkan denganrotary evaporator hingga didapat fraksi cair.

\section{Uji Daya Antibakteri}

Uji daya antibakteri menggunakan metode difusi yaitu metode lubang. Siapkan cawan petri yang telah disterilkan kemudian tuangkan $100 \mu \mathrm{L}$ suspensi bakteri lalu tambahkan media NA, homogenkan dan biarkan memadat. setelah itu dibuat lubang sumuran menggunkan tip mikropipet. Kemudian masukkan larutan uji fraksi etanol, nheksan dan kloroform daun labu siam dengan konsentrasi $100 \%$, sebagai kontrol positif diperlukan klorheksidin dan aquadest sebagian kontrol negatif ke 
dalam lubang-lubang tersebut dengan menggunakan mikropipet. Semua cawan petri diinkubasi selama 24 jam pada suhu $37^{\circ} \mathrm{C}$. Selanjuntnya dilakukan pengamatan dan pengukuran zona hambat yang terbentuk disekeliling lubang sumuran dengan menggunakan jangka sorong.

\section{Uji KLT dan Bioautografi}

lempeng $\mathrm{KLT}$ yang akan digunakan diaktifkan dengan pemanasan dalam oven pada suhu $110^{\circ} \mathrm{C}$ selama 30 menit. Fraksi etanol,n-heksan dan kloroform daun labu siam ditotolkan sebanyak 3 kali penotolan pada lempeng KLT ukuran $1 \mathrm{~cm} \times 7 \mathrm{~cm}$ menggunakan pipa kapiler, dibiarkan beberapa menit hingga kering dan dimasukkan kedalam chamber (bejana kromatografi) yang sudah jenuh dengan cairan pengelusi fase gerak dilakukan dengan berbagai perbandingan, dan didapatkan pemisahan paling baik yaitu kloroform:metanol:air (2:5:3) (v/v/v) [16] untuk fraksi etanol Fase gerak untuk fraksi kloroform didapatkan pemisahan paling baik yaitu kloroform;methanol (9:1). Fase gerak untuk fraksi n-heksan didapatkan pemisahan paling baik yaitu dengan menggunakan fase gerak n-heksan: kloroform (7:3). [19]. Lempeng dibiarkan terelusi sampai fase gerak mencapai batas yang diinginkan. Lempeng dikeluarkan dari bejana, kemudian Plat KLT dikeluarkan dan dikeringkan, noda yang tampak pada kromatogram kemudian diamati pada sinar UV dengan panjang gelombang $254 \mathrm{~nm}$ dan $366 \mathrm{~nm}$. Kemudian bercak dideteksi dengan pereaksi semprot Bouchardat untuk alkaloid dan akan menunjukkan warna merah, jingga dan coklat. Ammonia untuk flavonoid menunjukkan warna kuning, hijau, coklat atau merah muda. $\mathrm{FeCl}_{3}$ untuk tanin akan menghasilkan warna hijau, merah, ungu, biru atau hitam kuat. Liebermann-Burchard untuk saponin. $\mathrm{H}_{2} \mathrm{SO}_{4}$ untuk terpen akan menghasilkan warna kuning, hijau, coklat atau merah muda. [16].
Kemudian hitung $\mathrm{Rf}$ yang diperoleh. Senyawa aktif yang mempunyai aktivitas antibakteri kemudian dideteksi menggunakan metode bioautografi dengan cara plat hasil elusi ditempelkan pada permukaan media agar dalam petri yang masing-masing telah diinokulasi dengan suspensi bakteri P.gingivalis dan $S$. mutans. Setelah 3 jam lempeng tersebut diangkat dan dipindahkan kemudian diinkubasi pada suhu $37^{\circ} \mathrm{C}$ selama 24 jam lalu diamati zona hambatan yang terbentuk lalu hitung Rf nya. Kemudian bandingkan hasil nilai $\mathrm{Rf}$ yang diperoleh pada KLT Bioautografi dengan hasil nilai Rf pada plat KLT [16].

\section{Analisis Data}

Data hasil uji dianalisis dengan metode One Way Anova dengan uji lanjut LSD dan tukey dengan uji lanjut Mann-Whitney Testmenggunakan software SPSS versi 24.

\section{HASIL DAN PEMBAHASAN}

\section{Ekstrak Dan Fraksi daun labu siam}

Simplisia daun labu siam sebanyak 500 gram masukan kedalam botol gelap kemudian ekstrak dibuat dengan cara maserasi menggunakan cairan penyari etanol $70 \%$ Pengambilan senyawa aktif yang terkandung di daun labu siam dilakukan dengan metode maserasi. Metode ini termasuk dalam ekstraksi cara dingin yang dapat dilakukan tanpa menggunakan pemanasan sehingga kerusakan pada zat yang tidak tahan terhadap pemanasan dapat terhindari. Selain itu keuntungan lainnya adalah zatzat dalam sel-sel simplisia akan tertarik sempurna dari pelarut yang sesuai. Maserat di rotary evaporator sehingga mendapatkan ekstrak cair sebanyak 500 mL. Kemudian dilakukan fraksinasi terhadap ekstrak dengan berbagai jenis pelarut dengan berbagai tingkat kepolarannya yaitu nheksan (non polar), kloroform (semipolar), dan etanol (polar). Pelarut n-heksan digunakan untuk menarik senyawa yang bersifar non polar, 
pelarut kloroform untuk menarik senyawa yang bersifat semipolar dan pelarut etanol untuk menarik senyawa polar. Penggunaan ketiga pelarut tersebut untuk mendapatkan senyawa yang benerbener murni. Fraksi yang diperoleh yakni fraksi etanol (80 mL), kloroform (120 mL) dan $\mathrm{n}$ heksan $(100 \mathrm{~mL})$. Kemudian fraksi etanol yang diperoleh di uapkan hingga diperoleh volume fraksi cair $50 \mathrm{~mL}$ dan fraksi $\mathrm{n}$ heksan yang diperoleh di uapkan hingga diperoleh volume fraksi cair $50 \mathrm{~mL}$, kemudian fraksi kloroform di uapkan hingga didapat $50 \mathrm{~mL}$

\section{Bakteri Porphyromonas gingivalis}

Uji daya antibakteri daun labu siam dilakukan dengan menggunakan fraksi etanol, fraksi n-heksan dan fraksi kloroform dengan konsentrasi 100\% dengan klorheksidin sebagai kontrol positif dan aquadst sebagai kontrol negatif yang kemudian diujikan ke kedua jenis bakteri yang berbeda yaitu P.gingivalis dengan menggunakan metode sumuran dan media NA dalam uji antibakteri. Hasilnya dapat dilihat pada Gambar 1

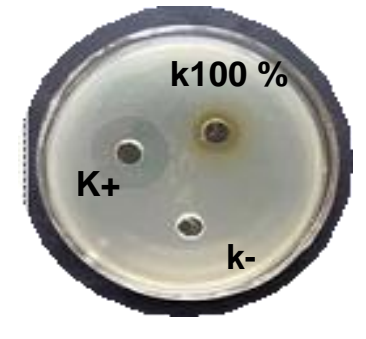

(A)

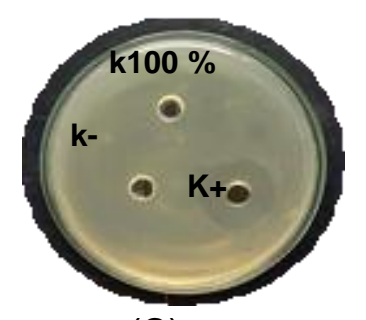

(C)

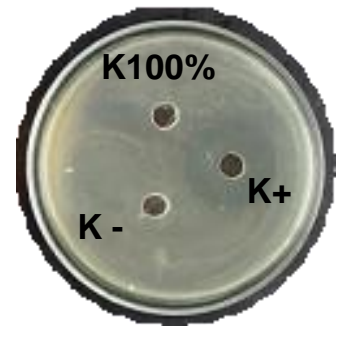

(B)
Gambar 1. Hasil uji daya antibakteri fraksi (A) etanol, (B) n-heksan, (C) kloroform daun labu siam terhadap bakteri. P.gingivalis Konsentrasi $100 \%$, kontrol positif (+) klorheksidin dan kontrol negatif (-) aquades
Hasil penelitian uji daya antibakteri menunjukkan bahwa fraksi etanol, daun labu siam dapat menghambat pertumbuhan bakteri gram negatif P.gingivalis dengan konsentrasi $100 \%$ sebesar 11,49. Sedangkan pada fraksi nheksan dan kloroform tidak menghasilkan zona hambat.

\section{Bakteri streptococcus mutans}

Uji daya antibakteri daun labu siam dilakukan dengan menggunakan fraksi etanol, fraksi n-heksan dan fraksi kloroform dengan konsentrasi 100\% dengan klorheksidin sebagai kontrol positif dan aquadst sebagai kontrol negatif yang kemudian diujikan ke kedua jenis bakteri yang berbeda yaitu $S$. mutans yang mewakili gram positif dengan menggunakan metode sumuran dan media NA dalam uji antibakteri. Hasilnya dapat dilihat pada Gambar 2

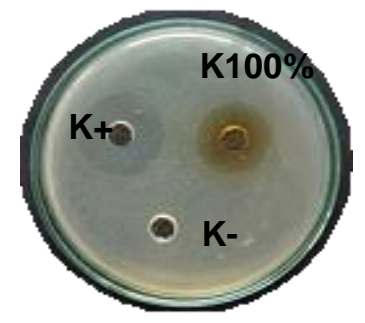

(A)

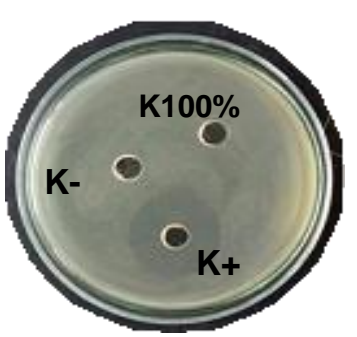

(C)

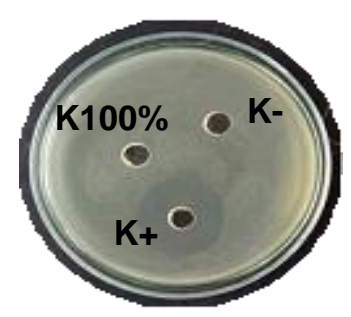

(B)
Gambar 2. Hasil uji daya antibakteri fraksi (A) etanol, (B) n-heksan, (C) kloroform daun labu siam terhadap bakteri. S.mutans Konsentrasi $100 \%$, kontrol positif (+) klorheksidin dan kontrol negatif $(-)$ aquades

Hasil penelitian uji daya antibakteri menunjukkan bahwa fraksi etanol, daun labu siam dapat menghambat 
pertumbuhan bakteri gram negatif S.mutans dengan konsentrasi 100\% sebesar 16,04 . Sedangkan pada fraksi $n-$ heksan dan kloroform tidak menghasilkan zona hambat.

Tabel 1. Rata-rata diameter zona hambat fraksi etanol terhadap bakteri $P$. gingivalis dan S. mutans.

\begin{tabular}{c|l|c|c|c|c|c}
\hline \multicolumn{7}{c}{ Diameter Zona Hambat $(\mathbf{m m})$} \\
\hline Bakteri & Perlakuan & $\mathbf{1}$ & $\mathbf{2}$ & $\mathbf{3}$ & Total & Rata-rata \\
\hline $\begin{array}{c}\boldsymbol{P} . \\
\text { gingivalis }\end{array}$ & $\mathrm{K}-$ & 0 & 0 & 0 & 0 & $0 \pm 0,000^{\mathrm{a}}$ \\
\cline { 2 - 7 } & $\mathrm{K}+$ & 17.02 & 18.98 & 17.70 & 53,7 & $17,9 \pm 0,984^{\mathrm{D}}$ \\
\cline { 2 - 7 } & $\mathrm{K} 100 \%$ & 11.03 & 11.94 & 11.50 & 34,47 & $11,49 \pm 0,455^{\mathrm{C}}$ \\
\hline \multirow{2}{*}{ S. mutans } & $\mathrm{K}-$ & 0 & 0 & 0 & 0 & $0 \pm 0,000^{\mathrm{a}}$ \\
\cline { 2 - 7 } & $\mathrm{K}+$ & 20.98 & 21.22 & 21.00 & 63,2 & $21,06 \pm 0,133^{\mathrm{D}}$ \\
\cline { 2 - 7 } & $\mathrm{K} 100 \%$ & 16.56 & 15.54 & 16.02 & 48,12 & $16,04 \pm 0,510^{\mathrm{C}}$ \\
\hline
\end{tabular}

Keterangan:Angka-angka pada kolom yang sama diikuti huruf tika atas yang sama tidak berbeda nyata.

$\mathrm{K}(-)$ :Menggunakan aquades

$\mathrm{K}(+)$ :Menggunakan antibiotik klorheksidin K100\%:Fraksi etanol daun labu siam dengan konsentrasi $100 \%$.

Hasil yang diperoleh pada pengujian antibakteri, fraksi yang menghasilkan diameter zona hambat adalah fraksi etanol, sedangkan pada fraksi n-heksan dan fraksi kloroform tidak menghasilkan diameter zona hambat. Hal ini dapat menunjukkan bahwa senyawa antibakteri dari fraksi daun labu siam lebih dapat tertarik dalam pelarut etanol yang bersifat polar. Uji daya dilanjutkan dengan menggunakan fraksi etanol dengan konsentrasi $100 \%$ dengan klorheksidin sebagai Kontrol positif $(+)$ dan aquadst sebagai Kontrol negatif (-) yang kemudian diujikan ke terhadap bakteri $P$. gingivalis dan S. mutans.

\section{Pengujian Secara KLT}

KLT yaitu metode yang digunakan untuk memisahkan senyawa secara fisika-kimia berdasarkan dengan komponen fase diam dan fase gerak. Analisis KLT bertujuan untuk mengetahui kandungan senyawa dari fraksi etanol, fraksi n-heksan dan fraksi kloroform daun labu siam. Sebelum dilakukan penotolan sampel, fase diam yang akan digunakan diaktivasi terlebih dahulu didalam oven selama 30 menit dengan suhu $110^{\circ} \mathrm{C}$. Kemudian chamber yang akan digunakan dijenuhkan terlebih dahulu menggunakan fase gerak terbaik kloroform:metanol:air (2:5:3) (v/v/v) untuk fraksi etanol dan fase gerak kloroform:metanol (9:1) untuk fraksi kloroform fase gerak n-heksan: kloroform (7:3) untuk fraksi n-heksan [16]. Plat KLT yang telah dielusi dengan fase gerak, kemudian diamati bercaknya di UV 254 dan di UV $366 \mathrm{~nm}$. Selanjutnya bercak tadi ditetesi dengan reagen semprot yaitu amoniak untuk senyawa flavonoid dan akan menunjukkan warna kuning, jingga atau merah, LibermannBouchard akan menghasilkan warna ungu untuk senyawa saponin, $\mathrm{H}_{2} \mathrm{SO}_{4}$ untuk steroid/triterpenoid dan akan menunjukkan warna coklat atau merah muda dan $\mathrm{FeCl}_{3}$ untuk tanin akan menghasilkan warna hijau, merah, ungu, biru atau hitam kuat

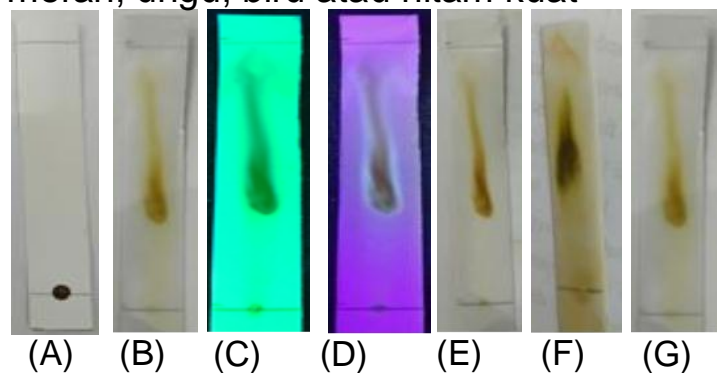

Gambar 3. Hasil Penampang Bercak Uji Kromatografi Lapis Tipis Fraksi Etanol daun labu siam Dengan Fase Gerak Kloroform:Metanol:Air (2:5:3). A: hasil penotolan, B: sinar tampak, C: UV 366, D : UV 254, E: Ammonia, (Flavonoid) F: $\mathrm{FeCl}_{3}$ (Tanin) G: Liberman (Saponin) 


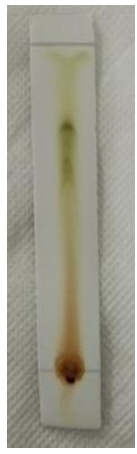

(A)

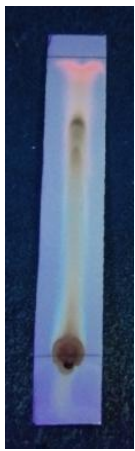

(B)

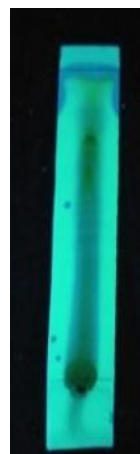

(C)

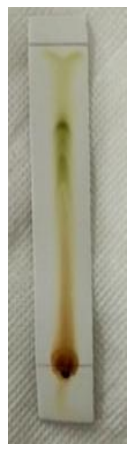

(D)

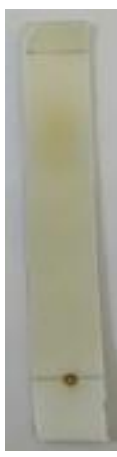

(A)

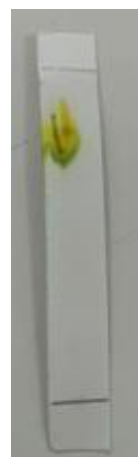

(B)

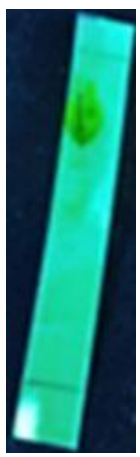

(C)

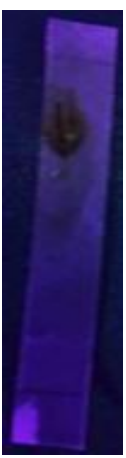

(D)

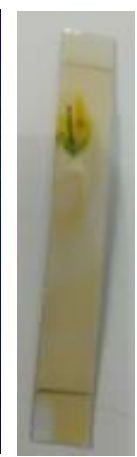

(E)

Gambar 5. Hasil Penampang Bercak Uji Kromatografi Lapis Tipis Fraksi n-heksan Daun labu siam Dengan Fase gerak n-heksan: kloroform (7:3) A : hasil penotolan B. sinar tampak, C: UV 254, D: UV 366, E: $\mathrm{H}_{2} \mathrm{SO}_{4}$ (Terpen)

Tabel 2. Hasil Penampang Bercak Kromatografi Lapis Tipis.

\begin{tabular}{c|c|c|c|c}
\hline Senyawa & Deteksi & Hasil positif & Hasil penelitian & Ket \\
\hline Tanin (polar) & $\mathrm{FeCl}_{3}$ & $\begin{array}{c}\text { Hijau, merah, ungu, } \\
\text { biru atau hitam kuat }\end{array}$ & Hitam kuat & + \\
\hline $\begin{array}{c}\text { Flavonoid } \\
\text { (polar) }\end{array}$ & Ammonia & $\begin{array}{c}\text { Kuning, hijau, coklat } \\
\text { atau htam kuat }\end{array}$ & Kuning & + \\
\hline Saponin (polar) & $\begin{array}{c}\text { Libermann- } \\
\text { burchard }\end{array}$ & Ungu & $\begin{array}{c}\text { Tidak } \\
\text { mengalami } \\
\text { perubahan }\end{array}$ & - \\
\hline $\begin{array}{c}\text { Alkaloid } \\
\text { (semi polar) }\end{array}$ & Libermann & Hidak & $\begin{array}{c}\text { mengalami } \\
\text { perubahan }\end{array}$ & - \\
\hline $\begin{array}{c}\text { Terpen } \\
\text { (non polar) }\end{array}$ & $\mathrm{H}_{2} \mathrm{SO}_{4}$ & $\begin{array}{c}\text { Kuning, hijau, } \\
\text { coklat,atau merah } \\
\text { muda }\end{array}$ & $\begin{array}{c}\text { Tidak } \\
\text { mengalami } \\
\text { perubahan }\end{array}$ & - \\
\hline
\end{tabular}

Hasil penampang bercak kromatografi lapis tipis menunjukkan hasil positif mengandung senyawa tanin setelah disemprot dengan $\mathrm{FeCl}_{3}$ yang ditandai dengan terbentuknya warna hitam kuat pada plat. Hasil penampang bercak kromatografi lapis tipis menunjukkan hasil positif mengandung senyawa flavonoid setelah disemprot dengan amonia dengan terbentuknya warna kuning pada plat dan hasil kromatografi lapis tipis menunjukkan hasil negatif mengandung saponin setelah disemprot dengan Libermann-Burchard karena tidak terbentuknya warna ungu pada plat, hasil penampang bercak negatif mengandung triterpenoid karena tidak terbentuk warna hijau pada plat dan negatif mengandung senyawa alkaloid setelah disemprot dengan LibermannBurchard karena tidak terbentuknya warna hijau pada plat. Bercak noda pada fraksi etanol daun labu siam dengan melihat hasil uji semprot dapat dinyatakan mengandung senyawa tanin dengan $\mathrm{Rf}$ 0,83 . Penelitian sebelumnya tentang phytochemical screening and TLC profiling of Various Extracts of Reinwardtia indica menunjukkan adanya senyawa yang sama dengan tanin yaitu dengan harga $\mathrm{Rf} 0,85$ [17]. Fraksi etanol daun labu siam setelah disemprot dengan amonia memberikan 
warna bercak yang menandakan adanya senyawa flavonoid, $\mathrm{Rf}$ yang dihasilkan yaitu 0,47 . Penelitian sebelumnya tentang phytochemical screening and TLC profiling of Various Extracts of Reinwardtia indica menunjukkan adanya senyawa yang sama dengan flavonoid yaitu dengan harga $R f$ 0,48 [17]. Hasil uji penampang bercak fraksi etanol daun labu siam menunjukkan

bahwa terdapat senyawa tanin dan senyawa flavonoid yang bersifat sebagai antibakteri.

\section{Pengujian Secara KLT-Bioautografi}

Hasil uji aktivitas antibakteri menunjukkan bahwa fraksi etanol daun labu siam memiliki aktivitas antibakteri, sehingga dilanjutkan ke uji bioautografi. Bioautografi merupakan metode untuk mendeteksi bercak pada kromatogram hasil KLT yang memiliki aktivitas antibakteri dengan cara menempelkan plat KLT pada permukaan media agar yang telah ditanami mikroorganisme. Letak senyawa aktif akan tampak sebagai zona bening dengan latar belakang keruh. Pada penelitian ini digunakan metode bioautografi kontak karena lebih mudah, sederhana dan paling sering digunakan.

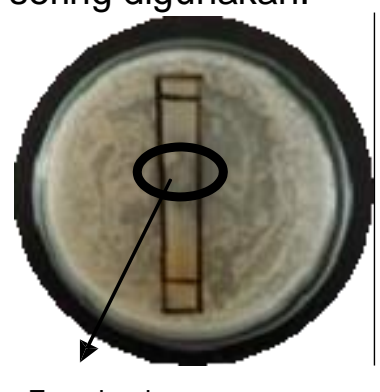

Zona bening

(A)

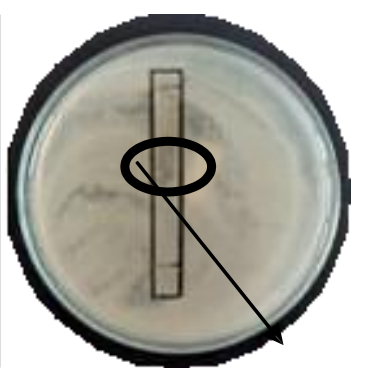

Zona bening

(B)
Gambar 6 Hasil bioautografi fraksi etanol daun labu siam dengan fase gerak kloroform: metanol : air (2:5:3) (v/v/v) terhadap bakteri $(A)$ $P$. gingivalis dan (B) $S$. mutans.
Zona bening yang terbentuk pada Gambar 4.6 menunjukkan adanya aktivitas antibakteri di kedua cawan dengan harga Rf yang terbentuk yaitu 0,49 , dimana memiliki nilai $\mathrm{Rf}$ yang mendekati $\mathrm{Rf}$ flavonoid pada uji KLT dengan harga Rf 0,47 yang merupakan senyawa flavonoid, sehingga senyawa aktif yang paling berperan sebagai antibakteri pada daun labu siam adalah senyawa flavonoid. Pada penelitian sebelumnya yaitu skrining fitokimia dari daun labu siam menunjukkan bahwa daun labu siam mengandung senyawa saponin, alkaloid steroid /triterpenoid, tanin dan flavonoid namun setelah dilakukan pengujian KLT Fraksi etanol daun labu siam mengandung senyawa flavonoid dan tanin.

Pengujian secara bioautografi menunjukkan bahwa kandungan kimia yang terdapat dalam fraksi etanol daun labu siam yang memiliki aktivitas antibakteri terhadap $P$. gingivalis dan S.mutans adalah senyawa flavonoid, terbukti dengan terbentuknya zona bening pada media dengan harga $\mathrm{Rf}$ sebesar 0,49 dan memiliki harga $\mathrm{Rf}$ yang mendekati dengan uji KLT pada senyawa flavonoid yaitu $R f$ 0,47 , yang menunjukkan warna kuning setelah disemprot dengan larutan Ammonia positif mengandung senyawa flavonoid.

\section{Identifikasi gugus fungsi dengan spektrofotometer Fourier Transform Infra Red (FTIR)}

Analisis serapan FTIR dilakukan untuk mengetahui gugus fungsi yang terkandung dalam fraksi etanol daun labu siam. Serapan yang muncul pada spektrum fraksi etanol daun labu siam terdapat pada wilayah 4000 sampai 650. Hasil pengukuran FTIR dari fraksi etanol daun labu siam dapat dilihat pada Gambar 7 


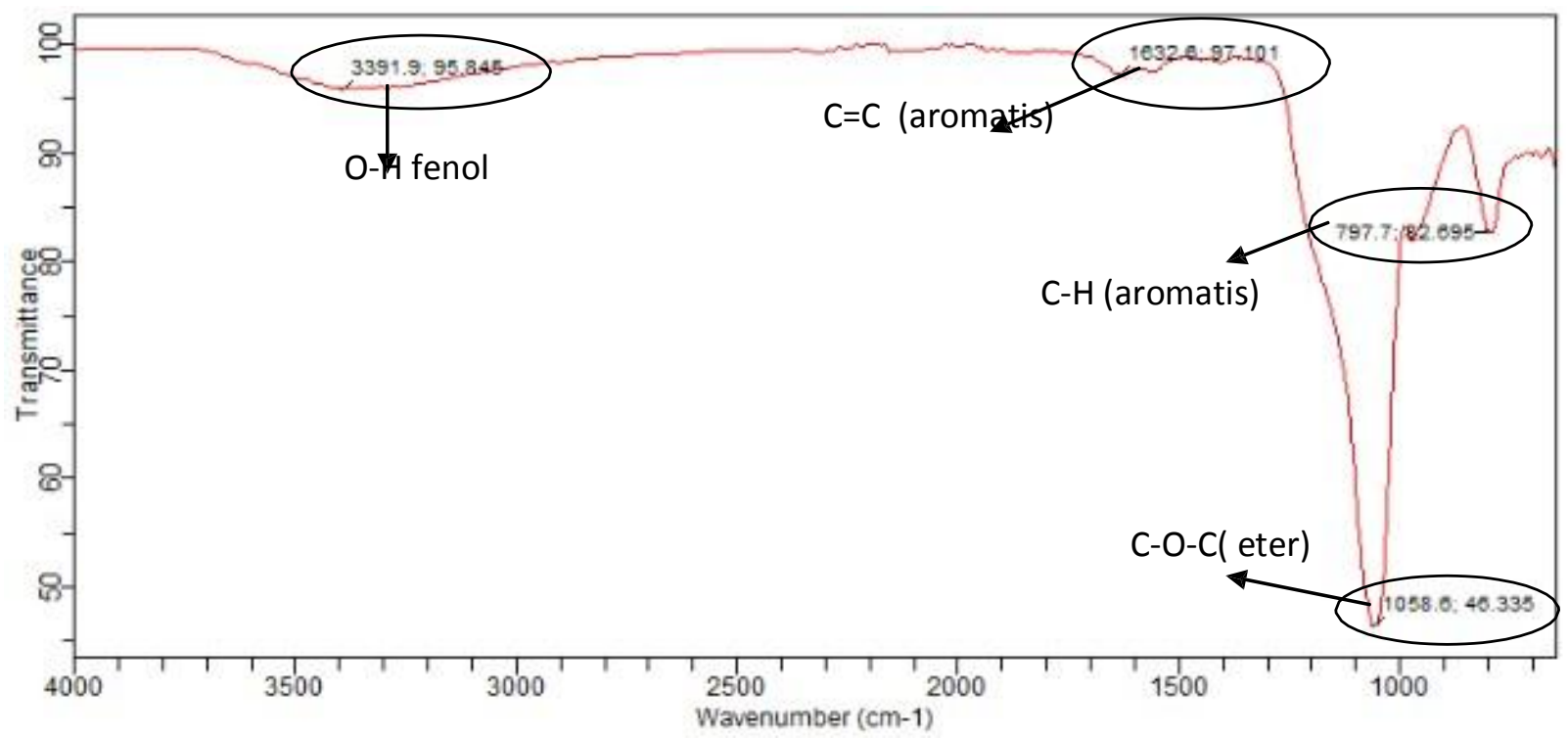

Gambar 7. Hasil Spektrum FTIR Fraksi Etanol Daun Labu Siam

Hasil pengujian FTIR diatas dapat dilihat bahwa terdapat 4 panjang gelombang pada fraksi etanol daun labu siam yaitu terdapat gugus $\mathrm{O}-\mathrm{H}$ dengan bentuk pita melebar pada panjang gelombang 3391 $\mathrm{cm}^{-1}$, pada kisaran daerah frekuensi 3200$3700 \mathrm{~cm}^{-1}$ termasuk kedalam golongan fenol. Dugaan tersebut diperkuat oleh serapan pada panjang gelombang 1058 $\mathrm{cm}^{-1}$ menunjukkan adanya gugus $\mathrm{C}-\mathrm{O}-\mathrm{C}$ termasuk kedalam golongan eter karena terletak pada daerah 1500-1000 $\mathrm{cm}^{-1}$. serapan pada panjang gelombang $1632 \mathrm{~cm}^{-}$ ${ }^{1}$ menunjukkan adanya gugus $\mathrm{C}=\mathrm{C}$, pada kisaran daerah frekuensi $1500-1000 \mathrm{~cm}^{-1}$ termasuk kedalam golongan aromatik. Dugaan tersebut diperkuat oleh serapan panjang gelombang $790.2 \mathrm{~cm}^{-1}$ yang menunjukkan adanya gugus $\mathrm{C}-\mathrm{H}$ termasuk kedalam golongan aromatik karena terletak pada daerah frekuensi $675-995 \mathrm{~cm}^{-1}$.

\begin{tabular}{c|c|c|c|c}
\hline No & Fraksi & $\begin{array}{c}\text { Bilangan } \\
\text { gelombang }\left(\mathbf{c m}^{\mathbf{- 1}}\right)\end{array}$ & $\begin{array}{c}\text { Rentang panjang } \\
\text { gelombang }\left(\mathbf{c m}^{-1}\right)\end{array}$ & Gugus fungsi \\
\hline 1 & Etanol & 3391 & $3200-3700 \mathrm{~cm}^{-1}$ & O-H fenol \\
\hline 2 & Etanol & 1058 & $1500-1000 \mathrm{~cm}^{-1}$ & C-O-C eter \\
\hline 3 & Etanol & 1632 & $1500-1000 \mathrm{~cm}^{-1}$ & $\mathrm{C}=\mathrm{C}$ aromatic \\
\hline 4 & Etanol & 790.2 & $675-995 \mathrm{~cm}^{-1}$ & C-H aromatik \\
\hline
\end{tabular}

Hasil analisis FTIR fraksi etanol daun labu siam menunjukkan adanya gugus $\mathrm{O}-\mathrm{H}$ fenol, C-O-C eter, C-H aromatik dan $\mathrm{C}=\mathrm{C}$ aromatik. Penelitian lain tentang karakterisasi senyawa flavonoid dari fraksi etil asetat nusa indah (mussaenda erythrophylla) menjelaskan bahwa gugus fungsi $\mathrm{O}-\mathrm{H}$ fenol, $\mathrm{C}-\mathrm{O}-\mathrm{C}$ eter, $\mathrm{C}-\mathrm{H}$ aromatik dan $\mathrm{C}=\mathrm{C}$ aromatik termasuk kedalam senyawa flavonoid [18]. Pada gugus fungsi keton tidak terdeteksi di grafik kemungkinan karna rendahnya transmittance.
Hasil Karekterisasi FTIR yang membedakan antar golongan gugus fungsi flavonoid dengan golongan gugus fungsi tanin yang terdapat didalam daun labu siam adalah gugus fungsi eter ( $\mathrm{C}-\mathrm{O}$ C). Senyawa tanin tidak memiliki gugus fungsi golongan fungsi eter sehingga senyawa yang diduga aktifitas anti bakteri berdasarkan FTIR adalah gugus flavonoid atau turunannya berikut struktur krangka dasar golongan flavonoid. 


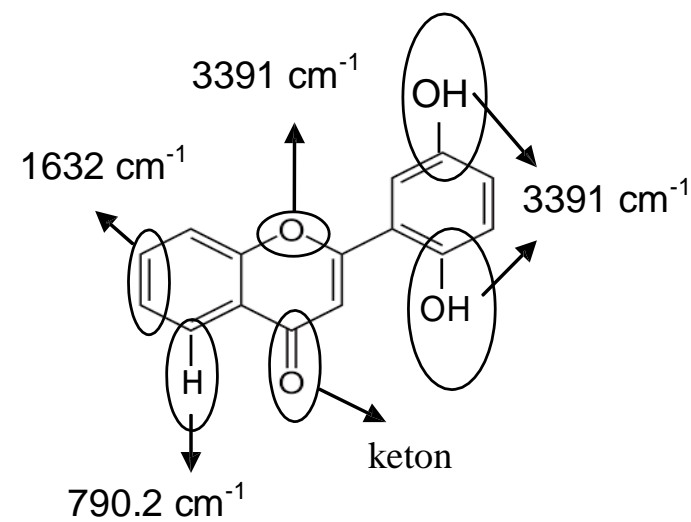

Gambar 8. Dugaan struktur senyawa flavonoid yang terdapat dalam daun labu siam

Hasil uji antibakteri menunjukkan bahwa flavonoid pada daun labu siam menghasilkan diameter zona terhadap bakteri $p$. gingivalis dan $S$. mutans. Hal ini menunjukkan bahwa yang berperan aktif dalam menghambat pertumbuhan bakteri adalah flavonoid. Flavonoid menghambat pertumbuhan bakteri dengan cara merusak dinding sel, menonaktifkan kerja enzim, berikatan dengan adhesin, dan merusak membran sel. Cincin beta dan gugus $-\mathrm{OH}$ pada flavonoid diduga sebagai struktur yang bertanggungjawab sebagai aktivitas antibakteri [18].

\section{KESIMPULAN DAN SARAN}

\section{A. KESIMPULAN}

Berdasarkan hasil penelitianyang telah dilakukan dapat disimpulkan bahwa:

1. Fraksi etanol daun Labu siam memiliki aktivitas antibakteri terhadap $P$.gingivalis dan S.mutans. Sedangkan fraksi n-heksan dan kloroform tidak memiliki aktivitas antibakteri P.gingivalis dan S.mutans.

2. Fraksi etanol daun labu siam terbukti mengandung senyawa flavonoid dan tanin, dan golongan senyawa aktif yang paling efektif menghambat bakteri pada fraksi etanol daun labu siam adalah senyawa flavonoid dengan harga $\mathrm{Rf} 0,49$

3. Gugus fungsi senyawa aktif berdasarkan karakterisasi FTIR pada fraksi etanol daun labu siam pada Rf
0,49 menunjukkan adanya gugus $\mathrm{OH}$ fenol, C-O-C eter, $\mathrm{C}=\mathrm{C}$ aromatik, $\mathrm{C}-\mathrm{H}$ aromatik.

\section{B. SARAN}

Perlu dilakukan isolasi dan identifikasi lebih lanjut mengenai senyawa antibakteri yang terdapat dalam ekstrak maupun fraksi daun labu siam yang mempunyai aktivitas antibakteri.

\section{UCAPAN TERIMAKASIH}

Ucapan terimakasih disampaikan kepada Staff Laboratorium Mikrobiologi dan Kimia Dasar Universitas Tulang Bawang Lampung.

\section{DAFTAR PUSTAKA}

[1]. Thresia U. Sapara, Waworuntu O, Juliatri. 2016. Efektivitas Antibakteri Ekstrak Daun Pacar Air (Impatiens balsamina L.) Terhadap pertumbuhan Porphyromonas gingivalis. Jurnal IImiah Farmasi. 5(04):10-17.

[2]. Fatimah I.A, Kusumawardani B, Meilawaty Z, Wulan Suci A. 2016. Pengaruh Ekstrak Flavonoid Rendah Nikotin Limbah Daun Tembakau Kasturi (Nicotiana tabaccum L.) Terhadap Pertumbuhan Mikroba Rongga Mulut. Fakultas Kedokteran Gigi Universitas Jember.

[3]. Paliling A, Posangi J, Anindita P.S. 2016. Uji Daya Hambat Ekstrak Bunga Cengkeh (Syzygium aromaticum) terhadap bakteri 
Porphyromonas gingivalis. Jurnal eGiGi (eG). 4(02):299-234.

[4]. Juvensius R. Andries, Paulina N. Gunawan, Supit A.2014.uji efek anti bakteri ekstrak bunga cengkeh terhadap bakteri Streptococcus mutans secara in vitro. Jurnal e-GiGi (eG). 2(02):1-8.

[5]. Sabir A. 2005. Aktivitas antibakteri flavonoid propolis Trigona $\mathrm{sp}$ terhadap bakteri Streptococcus mutans (in vitro). Jurnal Majalah Kedokteran Gigi. 38(03):135-141.

[6]. Fajriani, Andriani N.J. 2014. Reduction of Salivary Streptococcus mutans Colonies in Children After Rinsing with 2.5\% Green Tea Solution. Journal of Dentistry Indonesia. 21(03):81-86.

[7]. Anggayanti A.N, Adiatmika, Adiputra N. 2013. Berkumur dengan teh hitam lebih efektif daripada Chlorhexidine gluconate $0,2 \%$ untuk menurunkan akumulasi plak gigi. Jurnal PDGI. 62(02):35-40.

[8]. Fitri. 2018. Fraksi Etanol Rimpang Jeringau (Acorus calamus L.) sebagai Antibakteri Terhadap Staphylococcus aureus dan Escherichia coli. Skripsi Fakultas Matematika dan IImu Pengetahuan Alam.

[9]. Zulfan M. Alibasyah, Andayani R, Farhana A. 2016. potensi antibakteri ekstrak jahe (Zingiber officinale Roscoe) terhadap Porphyromonas gingivalis secara in vitro. Journal of Syiah Kuala Dentistry Society 1(02):147-152.

[10]. Putri H, Barid I, wardani B.K. 2014. Daya Hambat Ekstrak Daun Tembakau terhadap Pertumbuhan Mikroba Rongga Mulut Stomatognatic. Jurnal Kedokteran Gigi 11(02)27-31.
[11]. Zuhrawati, Asmilia N, Rizky A, Zuraidawati, Nazaruddin, Adam M, Muttaqien. $2015 . \quad$ Pengaruh pemberian infusa daun labu siam (Sechium edule) Terhadap kadar hemoglobin dan nilai hematokrit Tikus putih (Rattus norvegicus) anemia. Jurnal Medika Veterinaria. 9(02)80-84.

[12]. Ratnayani K, Ayuseptri J. A.A, Mayun Laksmiwati A,A,I, Dewi P.K IG.A. 2015. Uji aktivitas protease getah labu siam dan talas serta Perbandingannya terhadap getah pepaya. Jurnal Kimia 9(02)147-152.

[13]. Ordonez A.A.L, Gomez J.D, Vattuone M.A, Isla M.I..2006. Antioxidant activities of Sechium edule (Jacq.) Swartz extracts. Journal Food Chemistry 97.p 452-458.

[14]. Ordoñez A. A. L., Gomez J. D. Dudmani N. M, Vattuone M. A. \& M. I. Isla. 2013. Antimicrobial Activity of Nine Extracts of Sechium edule (Jacq.) Swartz. Journal Microbial Ecology in Health and Disease. 15 :33-39.

[15]. Arifurrahman. 2017. pengaruh ekstrak etanol daun labu siam (Sechium edule (Jacq.) SW ) terhadap daya hambat pertumbuhan Bakteri Porphyromonas gingivalis penyebab Periodontitis. Skripsi Universitas Muhammadiyah Surakarta.

[16]. Galuh Gondo Kusumo, M.A. Hanny Ferry, Heppy Asroriyah. 2017. Identifikasi Senyawa Tanin Pada Daun Kemuning (Murraya panicullata L. Jack) Dengan Berbagai Jenis Pelarut Pengekstraksi. Journal of Pharmacy and Science. 2(1):29-32.

[17]. Sonam mehta, Rana PS, Saklani pooja. 2017. Phytochemical screening and TLC profiling of Various Extracts of Reinwardtia 
indica. International Journal of Pharmacognosy and Phytochemical Research 9(4); 523-527.

[18]. Nugraha A.C ,Prasetya A.T, Mursiti S 2017 Isolasi, Identifikasi, Uji Aktivitas Senyawa Flavonoid sebagai Antibakteri dari Daun Mangga. Indonesian Journal of Chemical Science. 6(2):95.

[19]. Zuhrawati, Asmilia N, Rizky A, Zuraidawati, Nazaruddin, Adam M, Muttaqien. 2015. Pengaruh pemberian infusa daun labu siam (Sechium edule) Terhadap kadar hemoglobin dan nilai hematokrit Tikus putih (Rattus norvegicus) anemia. Jurnal Medika Veterinaria. 9(02)80-84.

[20].Febrianasari T. 2018. Aktivitas antibakteri dan bioautografi fraksi etanol bunga soka (Ixora coccinea L.) terhadap bakteri S.aureus dan E.coli (skripsi). Universitas Tulang Bawang Lampung 